\title{
Sistem Penyiraman Tanaman Otomatis Menggunakan Metode Logika Fuzzy
}

\author{
Budi Sugandi $^{{ }^{*}}$, dan Jeki Armentaria ${ }^{1}$ \\ ${ }^{1}$ Politeknik Negeri Batam, Batam, Indonesia \\ *Email: budi_sugandi@polibatam.ac.id
}

\begin{abstract}
Abstrak-Salah satu tantangan dalam budi daya tanaman adalah masalah penyiraman tanaman. Sebagian besar proses penyiraman dilakukan secara konvensional. Penelitian ini mengusulkan salah satu pemecahan masalah penyiraman dengan suatu sistem kontrol penyiraman tanaman otomatis menggunakan logika fuzzy. Sistem yang diusulkan dengan menggunakan dua kriteria yaitu kondisi udara (suhu) dan kondisi tanah (kelembaban). Sistem yang dikembangkan menghasilkan keluaran berupa durasi waktu penyiraman dalam empat kriteria yaitu sangat cepat, cepat, sedang dan lama. Hasil pengujian terhadap kondisi suhu menunjukan error rata-rata sebesar $0.41 \%$, sedangkan pengujian kelembaban menunjukan error rata-rata sebesar $2.3 \%$. Rata-rata durasi waktu penyiraman yang dihasilkan oleh sistem adalah 33.1 detik.
\end{abstract}

Kata kunci: penyiraman tanaman, logika fuzzy, suhu, kelembaban

\section{Pendahuluan}

PENYIRAMAN tanaman adalah salah satu pekerjaan yang monoton, rutin dan dilakukan secara konvensional.yang biasanya memunculkan berbagai permasalahan. Salah satunya adalah tidak ada ukuran kuantitas air yang sama dalam tiap penyiraman yang akan mengakibatkan tanaman yang dirawat bisa mengalami kelebihan ataupun kekurangan air sehingga akhirnya mengalami pembusukan dan mati [1]. Permasalahan akan lebih kompleks jika tanaman yang dirawat merupakan tanaman yang membutuhkan perawatan yang lebih spesifik dan intensif, karena dibutuhkan pola penyiraman yang spesifik dan intensif pula. Penyiraman tanaman yang hemat dan tepat waktu merupakan salah satu solusi. Sehingga akan membantu jika ada suatu sistem penyiraman otomatis yang dapat melakukan penyiraman secara merata sesuai dengan kebutuhan [2].

Beberapa studi sudah dilakukan untuk mengatasi berbagai permasalahan di atas, diantaranya Pranata dkk yang mengusulkan logika fuzzy pada penyiraman tanaman seledri yang menghasilkan pengendalian kelembaban tanah pada $73.9 \%$ [3]. Penelitian lainnya mengusulkan proses penyiraman dengan kondisi suhu dan kelembaban dengan membagi setiap kondisi dalam tiga keadaan [4]-[6]. Sementara Wijaya, dkk, mengusulkan pengembangan penyiraman otomatis dengan metode fuzzy Sugeno untuk meningkatkan keefektifan manajemen penyiraman [7].

Dalam studi ini, kami mengusulkan solusi lain untuk mengotomasi proses penyiraman tanaman menggunakan metode logika fuzzy dengan menggunakan dua parameter utama yaitu suhu udara dan kelembaban tanah. Tiap parameter menggunakan menggunakan lima kriteria. Solusi yang diusulkan adalah untuk mengatur durasi waktu penyiraman berdasarkan kondisi udara dan kondisi tanah. Durasi waktu penyiraman dikaterogrikan dalam empat kelompok. Sehingga diharapkan metode ini dapat mengatur debit air yang dibutuhkan dalam proses penyiraman tanaman.

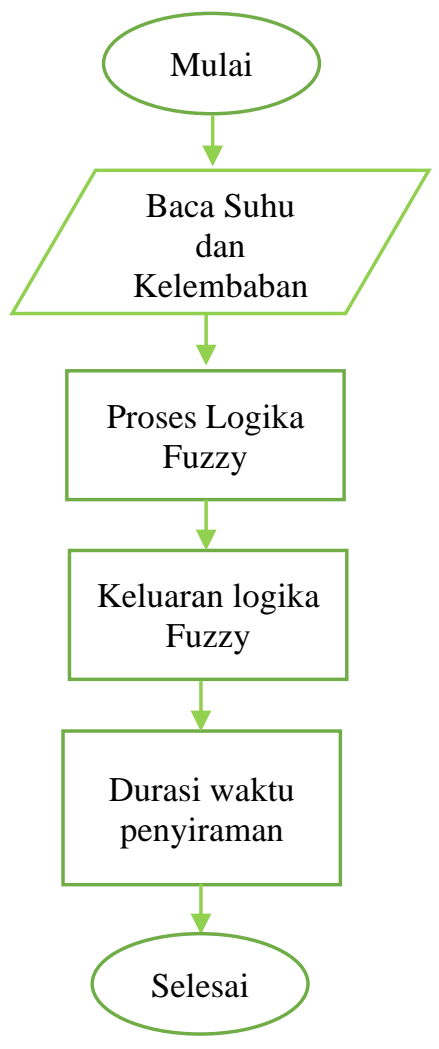

Gambar 1. Diagram alir sistem 


\section{Metode}

Pada penelitian ini, sistem yang diusulkan dirancang untuk menyiram tanaman berdasarkan dengan dua kondisi yaitu kondisi udara (suhu) dan kondisi tanah (kelembaban). Data dua kondisi ini akan diolah oleh sistem pengendali menggunakan logika fuzzy. Sistem akan menghasilkan output berupa durasi waktu penyiraman dengan cara menghidupkan pompa air secara otomatis yang dikendalikan oleh sistem pengendali. Sementara hasil pembacaan suhu dan kelembaban akan ditampilkan pada display LCD. Metode penelitian yang dilakukan pada sistem penyiraman tanaman otomatis dapat dilihat pada gambar 1. Sementara blok diagram sistem yang dirancang ditunjukkan pada gambar 2. Input dari sistem dibaca oleh sensor suhu dan kelembaban untuk kemudian diolah dan diproses oleh mikrokontroler menggunakan logika fuzzy. Hasil pengolahan suhu dan kelembaban ini akan menghasilkan durasi waktu pembukaan solenoid valve sebagai pengatur durasi waktu penyiraman atau kuantiras air yang dipakai penyiraman. Display LCD digunakan untuk menampilkan kondisi suhu dan kelembaban yang terukur oleh sensor suhu dan kelembaban.

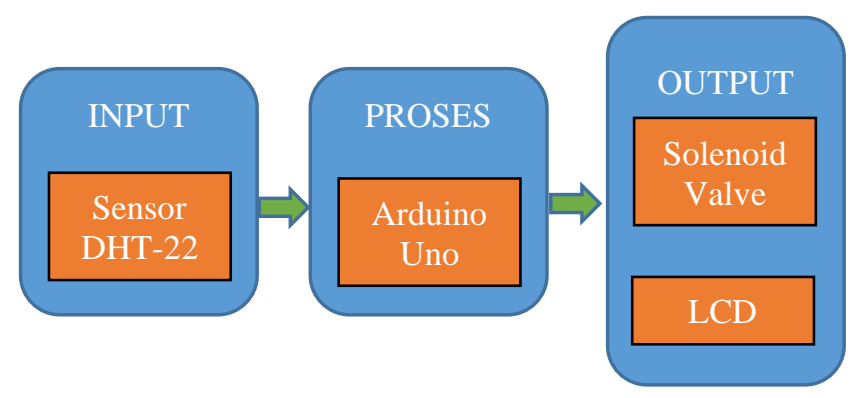

Gambar 2. Diagram blok sistem

Proses logika Fuzzy merupakan inti dari perancangan sistem yang dilakukan dalam studi ini. Berikut tahapan yang dilakukan dalam merancang proses logika fuzzy.

\section{A. Fuzzifikasi}

Tahap pertama pada proses logika fuzzy adalah proses fuzifikasi yaitu tahap pembentukan fungsi keanggotaan logika fuzzy. Proses fuzifikasi dibagi dua yaitu fuzifikasi error dan fuzifikasi delta error. Kedua buah kelompok fuzifikasi ini digunakan untuk menambah parameter dari himpunan fuzzy.

Nilai masukan fuzifikasi error berasal dari set point yang diinginkan dan nilai suhu serta kelembaban yang ditampilkan oleh sensor. Sedangkan untuk fuzifikasi delta error nilai masukan berasal dari selisih nilai error saat itu dan nilai error sebelumnya.

Pada studi ini, masukan pada fuzzy suhu yaitu error dan delta error suhu dengan range $-20{ }^{\circ} \mathrm{C}$ sampai $20{ }^{\circ} \mathrm{C}$. Dengan asumsi suhu udara $35^{\circ} \mathrm{C}$, maka suhu udara akan berkisar pada $15{ }^{\circ} \mathrm{C}$ sampai $55^{\circ} \mathrm{C}$. Gambar 3 dan gambar 4 menunjukkan fungsi keanggotaan dari error dan delta error suhu, dengan $N B=$ Negatif Besar, $N K=$ Negatif Kecil, $Z=\mathrm{Nol}, P K=$ Positif Kecil dan $P B=$ Positif Besar.

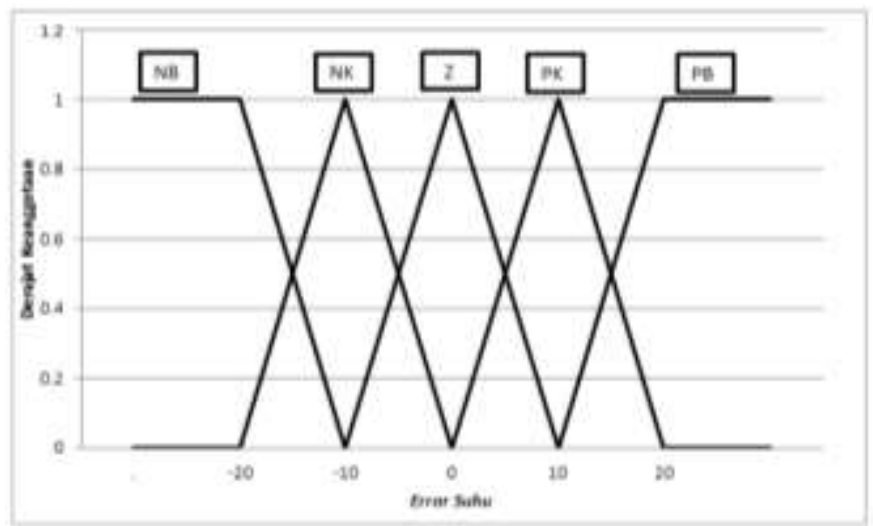

Gambar 3. Membership Function Error Suhu

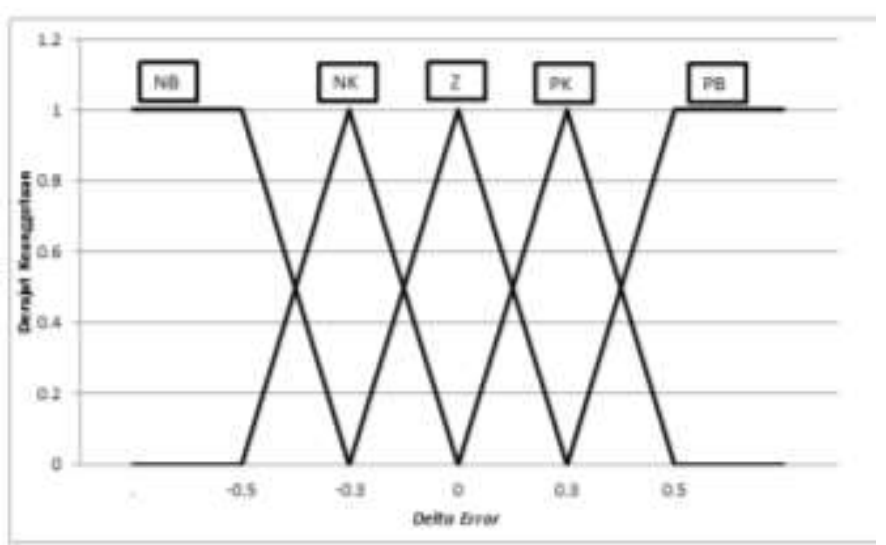

Gambar 4. Membership Function Delta Error Suhu

Sementara masukan fuzzy kelembaban yaitu error dan delta error kelembaban dengan range $-40 \%$ sampai $40 \%$. Dengan asumsi kelembaban berada pada $60 \%$, maka kelembaban ada pada range 20\% - 100\%. Gambar 5 dan gambar 6 menunjukkan fungsi keanggotaan dari error dan delta error kelembaban.

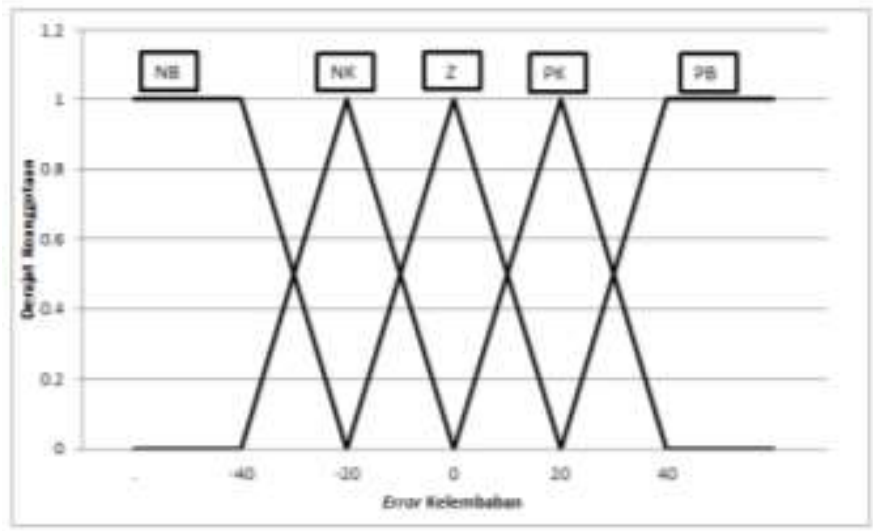

Gambar 5. Membership Function Error Kelembaban 


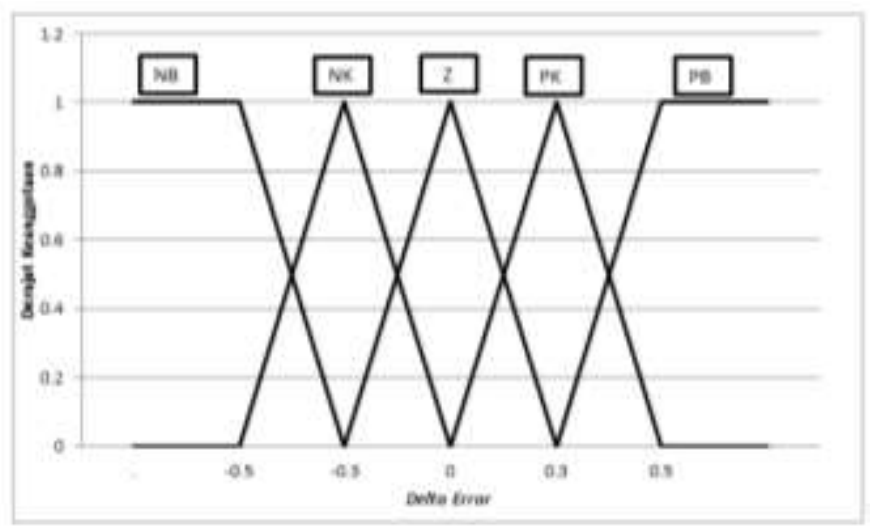

Gambar 6. Membership Function Delta Error Kelembaban

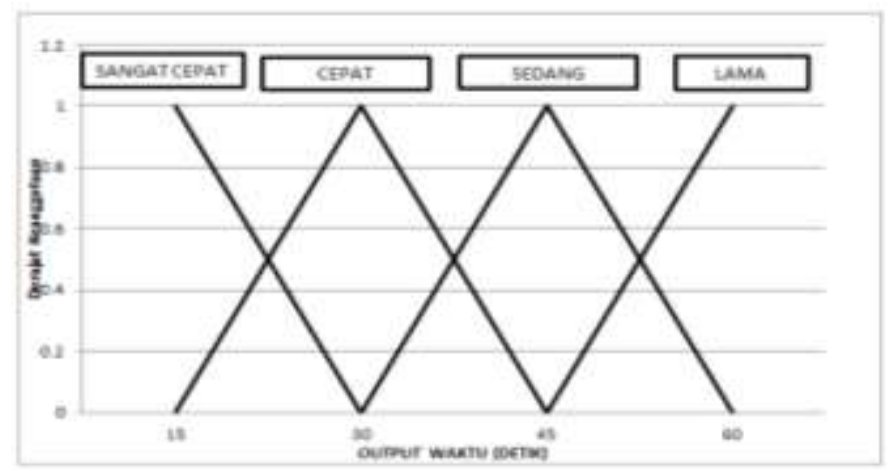

Gambar 7. Membership Fucntion Output durasi waktu penyiraman

Keluaran dari proses logika fuzzy dirancang berupa durasi waktu proses penyiraman. Dalam studi ini didefinisikan dalam empat kriteria durasi waktu yaitu sangat cepat, cepat, sedang dan lama dengan masing-masing 15, 30, 45 dan 60 detik seperti ditunjukkan pada gambar 7 .

\section{B. Rule Base}

Tahap kedua pada proses fuzzy adalah Rule Base, yaitu penentuan aturan-aturan fuzzy untuk kedua input dan output. Untuk aturan fuzzy yang digunakan seperti yang ditunjukkan oleh tabel I. Output yang dihasilkan yaitu output lamanya air mengalir dalam melakukan penyiraman.

TABEL I

RULE BASE FUZZY

\begin{tabular}{|c|c|c|c|c|c|}
\hline $\begin{array}{l}\text { Sensor } \\
\text { DHT22 } \\
\end{array}$ & NB & NK & Z & PK & PB \\
\hline NB & $\begin{array}{c}\text { Sangat } \\
\text { Cepat }\end{array}$ & $\begin{array}{c}\text { Sangat } \\
\text { Cepat }\end{array}$ & $\begin{array}{c}\text { Sangat } \\
\text { Cepat }\end{array}$ & $\begin{array}{c}\text { Sangat } \\
\text { Cepat }\end{array}$ & $\begin{array}{c}\text { Sangat } \\
\text { Cepat }\end{array}$ \\
\hline NK & $\begin{array}{l}\text { Sangat } \\
\text { Cepat }\end{array}$ & $\begin{array}{c}\text { Sangat } \\
\text { Cepat }\end{array}$ & $\begin{array}{c}\text { Sangat } \\
\text { Cepat }\end{array}$ & Cepat & Cepat \\
\hline Z & $\begin{array}{l}\text { Sangat } \\
\text { Cepat }\end{array}$ & $\begin{array}{c}\text { Sangat } \\
\text { Cepat }\end{array}$ & $\begin{array}{l}\text { Sangat } \\
\text { Cepat }\end{array}$ & Cepat & Cepat \\
\hline PK & $\begin{array}{c}\text { Sangat } \\
\text { Cepat }\end{array}$ & $\begin{array}{c}\text { Sangat } \\
\text { Cepat }\end{array}$ & Cepat & Sedang & Lama \\
\hline PB & $\begin{array}{c}\text { Sangat } \\
\text { Cepat }\end{array}$ & Cepat & Cepat & Lama & Lama \\
\hline
\end{tabular}

\section{HASIL DAN PEMBAHASAN}

\section{A. Pengujian Sensor}

Pengujian dilakukan di sore hari selama 10 hari. Hasil dari pengukuran termometer dijadikan hasil pengukuran suhu secara aktual. Tabel II menunjukkan hasil pengukuran masingmasing sensor dan aktual suhu dengan rata-rata error $0,41 \%$. Sementara tabel III menunjukkan hasil pengukuran masingmasing sensor dan aktual kelembaban dengan rata-rata error $2,3 \%$.

Hasil pengukuran suhu dan kelembaban oleh masingmasing sensor menunjukkan nilai error yang masih bisa ditoleransi dibandingkan keadaan aktual dari lingkungan sehingga bisa dijustifikasi pengukuran ini valid untuk dijadikan sebagai masukan bagi sistem yang akan diproses oleh logika fuzzy untuk menentukan keluaran berupa durasi waktu,

TABEL II

Data Hasil PengukURAn Suhu

\begin{tabular}{ccccc}
\hline $\begin{array}{c}\text { Hari } \\
\text { ke- }\end{array}$ & $\begin{array}{c}\text { Data Sensor 1 Data Sensor 2 } \\
\left({ }^{\circ} \mathrm{C}\right)\end{array}$ & $\begin{array}{c}\text { Data Aktual } \\
\left({ }^{\circ} \mathrm{C}\right)\end{array}$ & $\begin{array}{c}\text { Error Sensor } \\
(\%)\end{array}$ \\
\hline 1 & 31,5 & 31,5 & 32 & 1,56 \\
2 & 30,8 & 30,8 & 31 & 0,64 \\
3 & 34 & 34 & 34 & 0 \\
4 & 33 & 33 & 33 & 0 \\
5 & 31,7 & 31,7 & 32 & 0,94 \\
6 & 30,9 & 30,9 & 31 & 0,32 \\
7 & 29 & 29 & 29 & 0 \\
8 & 29,8 & 29,8 & 30 & 0,67 \\
9 & 35 & 35 & 35 & 0 \\
10 & 30,7 & 30,7 & 31 & 0,96 \\
\hline \multicolumn{5}{c}{ Rata-rata error } \\
\hline \hline
\end{tabular}

TABEL III

Data Hasil PengukURAn Kelembaban

\begin{tabular}{ccccc}
\hline \hline $\begin{array}{c}\text { Hari } \\
\text { ke- }\end{array}$ & $\begin{array}{c}\text { Data Sensor 1 } \\
(\%)\end{array}$ & $\begin{array}{c}\text { Data Sensor 2 } \\
(\%)\end{array}$ & $\begin{array}{c}\text { Data Aktual } \\
(\%)\end{array}$ & $\begin{array}{c}\text { Error Sensor } \\
(\%)\end{array}$ \\
\hline 1 & 60 & 60 & 60 & 0 \\
2 & 65 & 65 & 63 & 3,17 \\
3 & 50 & 50 & 48 & 4 \\
4 & 55 & 55 & 57 & 3,5 \\
5 & 60 & 60 & 62 & 3,22 \\
6 & 65 & 65 & 65 & 0 \\
7 & 70 & 70 & 70 & 0 \\
8 & 65 & 65 & 65 & 0 \\
9 & 55 & 55 & 53 & 3,77 \\
10 & 60 & 60 & 57 & 5,26 \\
\hline \multicolumn{5}{c}{ Rata-rata error } \\
\hline \hline
\end{tabular}

TABEL IV

Data Hasil Pengukuran DURasi Waktu Penyiraman

\begin{tabular}{cccc}
\hline \hline $\begin{array}{c}\text { Hari } \\
\text { ke- }\end{array}$ & $\begin{array}{c}\text { Suhu } \\
\left({ }^{\circ} \mathrm{C}\right)\end{array}$ & $\begin{array}{c}\text { Kelembaban } \\
(\%)\end{array}$ & $\begin{array}{c}\text { Durasi } \\
(\text { detik })\end{array}$ \\
\hline 1 & 31,5 & 60 & 30 \\
2 & 30,8 & 65 & 29 \\
3 & 34 & 50 & 45 \\
4 & 33 & 55 & 40 \\
5 & 31,7 & 45 & 44 \\
6 & 30,9 & 65 & 25 \\
7 & 29 & 70 & 29 \\
8 & 29,8 & 65 & 27 \\
9 & 35 & 55 & 30 \\
10 & 30,7 & 60 & 32 \\
\hline \multicolumn{4}{c}{ Rata-rata } \\
\hline \hline
\end{tabular}




\section{B. Keluaran Hasil Kendali Logika Fuzzy}

Dengan menggunakan data suhu dan kelembaban yang diperoleh pada tabel II dan tabel III, sistem kendali menggunakan logika fuzzy yang dirancang dalam sistem ini menghasilkan keluaran berupa durasi waktu penyiraman seperti yang ditunjukkan pada tabel IV. Durasi waktu ini sebagai acuan sistem untuk menyalakan sistem penyiraman tanaman. Rata-rata durasi waktu penyiraman yang diperoleh dari penelitian ini adalah 33,1 detik dan dikategorikan sebagai sebagai waktu yang cepat.

\section{KESIMPULAN}

Penelitian ini mengusulkan suatu sistem kontrol penyiraman tanaman otomatis menggunakan logika fuzzy dengan menggunakan dua kriteria yaitu kondisi udara (suhu) dan kondisi tanah (kelembaban). Sistem yang dikembangkan menghasilkan keluaran berupa durasi waktu penyiraman dalam empat kriteria yaitu sangat cepat, cepat, sedang dan lama. Hasil pengujian terhadap kondisi suhu menunjukan error rata-rata sebesar $0,41 \%$, sedangkan pengujian kelembaban menunjukan error rata-rata sebesar 2,3\%. Rata-rata durasi waktu penyiraman yang dihasilkan oleh sistem adalah 33,1 detik.

Penelitian ini masih perlu untuk dikembangkan terutama untuk melihat efektivitas penyiraman dan juga waktu penyiraman tanaman itu sendiri. Selain itu, jumlah sampel hari dan musim yang dipilih belum terwakili dalam penelitian ini. Karena musim yang berbeda akan menghasilkan suhu dan kelembaban yang berbeda sehingga akan mempengaruhi kinerja sistem kontrol yang telah dikembangkan. Beberapa faktor ini dan faktor lainnya akan menjadi penelitian lanjutan yang akan menyempurnakan sistem yang dikembangkan.

\section{REFERENSI}

[1] H. Yanto, A. Tusi dan S. Triyono, "The Application of Drip Irrigation System onCauliflower in A Green House, "Jurnal Teknik Pertanian Lampung, vol. 3, 2014.

[2] R. Fauziah, A. D. Susiladan E. Sulistyono, "Budidaya Bawang Merah pada Lahan Kering Menggunakan Irigasi Sprinkler pada berbagai Volume dan Frekuensi”, Jurnal Hortikultura Indonesia, vol 7(1), 2016.

[3] T. Prananta, B. Irawan and Ilhamsyah, "Penerapan Logika Fuzzy pada sistem Penyiraman Tanaman Otomatis Berbasis Mikrokontroler," in Coding Jurnal Komputer dan Apliaksi, vol. 3, 2015.

[4] A. S. Pangga, "Perancangan Mesin Penyiraman Taman Menggunakan Fuzzy Logic," Indonesian Journal of Engineering and Technology, vol $1,2018$.

[5] S. Mursalin, H, Sunardi dan Zulkipli, "Sistem Penyiraman Tanaman Otomatis Berbasis Sensor Kelembaban Tanah Menggunakan Logika Fuzzy", Jurnal Ilmiah Informatika Global, vol. 11, 2020

[6] B. Kurniawan dan F. Arifin, "Alat Penyiram Tanaman Otomatis Dengan Logika Fuzzy Berbasis Atmega16", Jurnal Elektronik Pendidikan Teknik Elektronika, vol. 5, 2015

[7] M.A. Wijaya,R. Hanifah, dan M. Manullang, "Purwarupa Penyiraman Otomatis Dengan Arsitektur Mqtt Dan Logika Fuzzy Sugeno Untuk Meningkatkan Keefektifan Manajemen Penyiraman Tanaman (Studi Kasus : Itera)", Jurnal Teknologi Informasi, vol 5, 2020. 